Vol 1, No 3, November 2020: 123-128, DOI: $10.34007 / \mathrm{ins.v113.22}$

\title{
PENINGKATAN KEMAMPUAN BERPIKIR KRITIS BIOLOGI SISWA MELALUI MODEL PROBLEM BASED LEARNING (PBL) DI NEGARA 6 SMA PADANGSIDIMPUAN
}

\section{IMPROVING CRITICAL THINKING ABILITY OF STUDENT BIOLOGY THROUGH PROBLEM BASED LEARNING (PBL) MODEL IN STATE 6 STATE SMA PADANGSIDIMPUAN}

\author{
Hasanah Nasution, Sahlan Tuah \& Nurmaini Ginting \\ Program Studi Pendidikan Biologi, Universitas Muhammadiyah Tapanuli Selatan, Indonesia \\ Diterima: 15 Maret 2021; Disetujui: 30 Maret 2021; Dipublish: 31 Maret 2021
}

*Coresponding Email: hasanah@gmail.com

\begin{abstract}
Abstrak
Penelitian ini bertujuan untuk meningkatkan kemampuan berpikir kritis siswa dalam bidang biologi. Teknik analisis dalam penelitian ini adalah analisis keterampilan berpikir kritis dan observasi. Jenis penelitian ini adalah PTC. Hasil evaluasi kemampuan berpikir kritis siswa dengan ketidakmampuan belajar diperoleh pada siklus I sebesar 51,51\% dan pada siklus II 84,85\% dari 33 siswa yang lulus tes kemampuan berpikir kritis, dan terjadi peningkatan pada siklus I ke II. adalah 33,34\%. \%. Hasil observasi siswa juga mengalami peningkatan siklus I sebesar 54,17\% dan siklus II 89,20\% mengalami peningkatan sebesar 35,03\%, observasi guru siklus I 67,19\% siklus II 92,19\% peningkatan $25 \%$.
\end{abstract}

Kata Kunci: Model Problem Based Learning; Peta Konsep; Kemampuan Pemecahan Masalah; Berpikir Kritis.

\begin{abstract}
This study aims to improve students' critical thinking skills in the field of biology. The analysis technique in this research is critical thinking skills analysis and observation. This type of research is PTC. The results of the evaluation of students' critical thinking skills with learning disabilities were obtained in the first cycle of $51.51 \%$ and in the second cycle $84.85 \%$ of the 33 students who passed the critical thinking ability test, and there was an increase in the first cycle to II. is $33.34 \%$. \%. The results of student observations also experienced an increase in cycle I of $54.17 \%$ and cycle II $89.20 \%$ an increase of $35.03 \%$, teacher observations in cycle I $67.19 \%$, cycle II $92.19 \%$ an increase of $25 \%$.
\end{abstract}

Keywords: Problem Based Learning Model; Concept Maps; Problem Solving Skill; Critical Thinking.

How to Cite: Nasution, H., Tuah, S., \& Ginting, N. (2020). Peningkatan Kemampuan Berpikir Kritis Biologi Siswa Melalui Model Problem Based Learning (Pbl) Di Negara 6 SMA Padangsidimpuan. Journal of Natural Sciences. Vol 1 (3): 123-128. 


\section{PENDAHULUAN}

Pembelajaran sains dapat menumbuhkembangkan kemampuan berpikir tingkat tinggi, yang didefinisikan sebagai proses dan keterampilan yang digunakan untuk memahami konsep, menerapkan, mensintesis, dan mengevaluasi informasi yang diterima atau informasi yang dihasilkan. Indikator berpikir kritis yaitu: 1) memberi penjelasan sederhana (elementary clarification), 2) membangun keterampilan dasar (basic support), 3) menyimpulkan (inference), dan 4) membuat penjelasan lebih lanjut (anvanced clarification), serta 5) menerapkan strategi dan taktik (strategies and tactics) (Purbaningrum, 2017).

Kemampuan berpikir belajar yang dimiliki siswa sangat erat kaitannya dengan rumusan tujuan pembelajaran yang direncanakan guru. Hal ini dipengaruhi juga dengan kemampuan guru sebagai perancang pembelajaran. Untuk itu guru dituntut menguasai metode pembelajaran yang dapat membuat siswa berinteraksi aktif dengan siswa lainnya, atau siswa dengan guru. Perilaku dan keberhasilan siswa dalam mengidentifikasi dan memahami mata pelajaran dapat diukur dari kemampuan berpikir siswa yang bersumber dari hasil penilaian pembelajaran.

Rendahnya kemampuan berpikir belajar biologi siswa terhadap suatu materi disebabkan oleh kurang perhatikan dengan sungguh-sungguh saat pembelajaran dimulai. Siswa juga kurang teliti saat mengerjakan soal dan tidak ada pertanyaan siswa atas bagian materi yang kurang dipahami/dimengerti. Oleh karena itu untuk mengatasi masalah-masalah yang timbul dari diri siswa mempelajari biologi, perlu dilakukan suatu perubahan atau renovasi pengajaran agar mata pelajaran biologi dapat dipahami siswa dengan baik. Disamping itu pada saat pembelajaran biologi diharapkan pada guru bidang studi biologi agar dapar memperkenalkan materi biologi itu dengan baik dan cara yang lebih menarik sehingga siswa yang keliru selama ini bahwa biologi merupakan pelajaran yang sulit akan hilang (Amijaya dkk, 2018).

Untuk meningkatkan keterampilan berpikir, seorang guru harus mampu menerapkan model pembelajaran yang dapat mempengaruhi keterampilan berpikir kritis siswa, misalnya memberi penjelasan sederhana, membangun keterampilan awal, kesimpulan, penjelasan lebih lanjut, strategi dan taktik Salah satu model yang dapat meningkatkan kemampuan berpikir adalah model PBL. 
Namun kenyataannya dari hasil wawancara pada tanggal 10 Oktober 2018 dengan salah satu guru bidang studi Biologi di SMA Negeri 6 Padangsidimpuan menjelaskan bahwa dalam proses belajar mengajar lebih sering menggunakan model pembelajaran langsung sehingga kelas masih didominasi oleh guru. Selain itu sarana dan prasarananya pun masih belum dipergunakan dengan sepenuhnya. Berdasarkan hasil evaluasi dari tes kemampuan berpikir kepada siswa kelas XI MIA-9 SMA Negeri 6 Padangsidimpuan dikhususkan dalam pembelajaran pada pokok bahasan struktur dan fungsi sistem peredaran darah. Dari hasil test diagnostik tersebut, yang dicobakan kepada siswa pokok bahasan struktur dan fungsi sel pada sistem peredaran darah yaitu siswa yang mampu mencapai nilai di atas KKM=75 adalah sebanyak 8 orang $(24,24 \%)$ dari 33 orang siswa yang mengikuti tes, 25 orang lainnya $(75,76 \%)$ nilainya tidak dapat memenuhi KKM atau dapat digolongkan nilai tes belajarnya masih rendah yang memperoleh nilai di bawah 75, siswa yang memperoleh keaktifan nilai kualifikasi sangat baik tidak ada, siswa yang memperoleh kualifikasi nilai baik 8 orang, siswa yang memperoleh kualifikasi nilai cukup hanya 9 orang siswa, siswa yang memperoleh kualifikasi nilai kurang berjumlah 11 orang siswa dan kualifikasi dan siswa yang memperoleh sangat kurang berjumlah 5 orang siswa.

Dari hasil observasi proses belajar mengajar pada tanggal 10 Oktober 2018 juga diperoleh bahwa persentase aktivitas siswa masih sangat rendah yaitu 30,30\% dengan kualifikasi nilai cukup dan hasil tersebut menunjukkan bahwa siswa pada kelas XI MIA-9 SMA Negeri 6 Padangsidimpuan menyatakan bahwa keaktifan siswa masih kurang saat belajar di ruangan dan guru pada ruangan kurang berkreatif dalam menyampaikan pembelajaran dan hanya penggunaan metode ceramah, penugasan dan tanya jawab, Selain dari hasil tes dan observasi siswa dan guru, kemampuan berpikir kritis siswa pada kelas XI MIA-9 SMA Negeri 6 Padangsidimpuan juga dapat dilihat dari nilai ulangan harian siswa yang penulis peroleh dari guru bidang studi, dimana nilai ulangan yang diperoleh dengan rata-rata dibawah KKM yaitu sebesar 65.

Arends (2008) Model PBL merupakan model pembelajaran yang mengembangkan keterampilan berpikir dan pemecahan masalah serta keterampilan intelektual. Menurut Kono (2016) Model pembelajaran berbasis masalah bersumber dari teori bahwa belajar merupakan proses dimana siswa secara aktif mengkonstruksi pengetahuannya. 
Menurut Supiandi \& Julung (2016) melalui Model PBL guru memahami cara menyajikan materi dengan memberikan masalah yang berkaitan dengan materi pelajaran terlebih dahulu kepada siswa sebelum pembelajaran dimulai, yang bermaksud supaya siswa ikut berpikir untuk menyelesaikan masalah-masalah yang diberikan kepada mereka. Menurut Apriyani (2017) Melalui model PBL guru mengajak siswa untuk dapat saling mendukung dan membantu satu sama lain dalam menguasai materi yang diajarakan oleh guru. Dengan begitu siswa akan lebih termotivasi dalam belajar untuk menjadi tim terbaik. Oleh karena itu, jika siswa agar timnya mendapat penghargaan, mereka harus saling membantu sesama dalam mempelajari materi pelajaran.

Berdasarkan permasalahan di atas, maka perlu dilakukan penelitian tentang peningkatan kemampuan berpikir kritis Biologi Siswa Melalui Model Problem Based Learning (PBL) Di Sma Negeri 6 Padangsidimpuan.

\section{METODE PENELITIAN}

Penelitian ini bersifat kolektif dengan Penelitian Tindakan Kelas. Model pembelajaran Problem Based Learning (PBL) tentang struktur dan fungsi sistem peredaran darah dengan harapan dapat meningkatkan keterampilan berpikir kritis siswa selama belajar biologi siswa kelas XI MIA-9 SMA Negeri 6 Padangsidimpuan Tahun Pelajaran 2018-2019.

\section{HASIL DAN PEMBAHASAN}

\section{Hasil pengujian hopotesis setiap variable penelitian.}

Meningkatkan nilai tes kemampuan berpikir kritis biologi siswa melalui penerapan model pembelajaran berbasis masalah pada mata pelajaran struktur dan fungsi peredaran darah dilihat dari tes belajar yang telah di ujikan pada siklus I, siklus II, pada siklus I memperoleh persentase ketuntasan 51,51\%, dan persentase siklus II sebesar $84,85 \%$ dan dari siklus I ke siklus II mengalami peningkatan sebesar 33,34\%. Meningkatnya aktivitas siswa dalam pembelajaran dilihat berdasarkan hasil observasi untuk aktivitas siswa melalui penerapan penerapan model PBL pada pokok bahasan struktur dan fungsi peredaran darah dilihat dari hasil siklus I diperoleh persentase sebesar 54,17\% dengan kualifikasi nilai cukup, dan pesentase siklus II 89,20\% dengan 
kualifikasi nilai sangat baik dari siklus I ke siklus II mengalami peningkatan sebesar 33,34\%. Meningkatnya kinerja guru dalam mengelola proses belajar mengajar melalui penerapan penerapan model PBL pada pokok bahasan struktur dan fungsi peredaran darah yang dilihat dari hasil observasi untuk responden guru siklus I persentase sebesar 67,19\% dengan kualifikasi nilai cukup, dan persentse siklus II sebesar 92,19\% dengan kualifikasi nilai sangat baik dari siklus I ke siklus II mengalami peningkatan sebesar 25\%.

\section{SIMPULAN}

Berdasarkan hasil penelitian yang telah dilakukan maka diperoleh kesimpulan yaitu, guru biologi memusatkan pembelajaran pada kegiatan belajar siswa, bertentangan dengan konsep pelajaran yang diajarkan. Sehingga guru selalu memotivasi siswanya untuk lebih giat dalam hal pembelajaran. Agar guru biologi mau menerapkan model PBL pada mata pelajaran lain sebagai alternatif untuk meningkatkan kemampuan berpikir kritis.

\section{DAFTAR PUSTAKA}

Amijaya, L. S., Ramdani, A., \& Merta, I. W. (2018). Pengaruh model pembelajaran inkuiri terbimbing terhadap hasil belajar dan kemampuan berpikir kritis peserta didik. Jurnal Pijar Mipa, 13(2), 94-99.

Apriyani, L., Nurlaelah, I., \& Setiawati, I. (2017). Penerapan model PBL untuk meningkatkan keterampilan berpikir kritis ditinjau dari kemampuan akademik siswa pada materi biologi. Quagga: Jurnal Pendidikan dan Biologi, 9(01).

Arends, R. I. (2008). Learning to Teach. Yogyakarta: Pustaka Pelajar.

Kono, R. (2016). Pengaruh Model Problem Based Learning (PBL) Terhadap Pemahaman Konsep Biologi Dan Keterampilan Berpikir Kritis Siswa Tentang Ekosistem Dan Lingkungan Di Kelas X SMA Negeri 1 Sigi. JSTT, 5(1).

Nasution, R.H., Ginting, N., \& Syari, M. (2020). Penerapan Model Pembelajaran Koopeatif Tipe Temas Games Tournament Untuk Meningkatkan Motivasi Belajar Biologi Siswa Di Sma Negeri 5 Padangsidimpuan. Journal of Natural Sciences, Vol.1 (2) Juli 2020 : 105-122.

Purbaningrum, K. A. (2017). Kemampuan berpikir tingkat tinggi siswa smp dalam pemecahan masalah matematika ditinjau dari gaya belajar. JPPM (Jurnal Penelitian dan Pembelajaran Matematika), $10(2)$.

Supiandi, M. I., \& Julung, H. (2016). Pengaruh Model Problem Based Learning (PBL) terhadap kemampuan memecahkan masalah dan hasil belajar kognitif siswa biologi SMA. Jurnal Pendidikan Sains, 4(2), 60-64. 